DOI: https://doi.org/10.3897/arb.v31.e01

\title{
LATITUDINAL DEPENDENCE OF THE STRATOSPHERIC OZONE AND TEMPERATURE RESPONSE TO SOLAR PARTICLES' FORCING ON 20 JANUARY 2005
}

\author{
Natalya Kilifarska \\ National Institute of Geophysics, Geodesy and Geography - Bulgarian Academy \\ of Sciences \\ e-mail: nkilifarska@geophys.bas.bg
}

Keywords: Solar cosmic rays, Solar proton events, Stratospheric temperature and ozone.

\begin{abstract}
This study examines the latitudinal-altitudinal variations of the midday $\mathrm{O}_{3}$ and temperature response to the forcing of the enhanced flux of energetic particles, during January 2005 Solar Proton Event $(S P E)$. We show that short-term response of the stratospheric $\mathrm{O}_{3}$ depends strongly on the latitude and the energy of precipitating particles. At polar latitudes, where the relativistic electrons and "soft" protons are able to penetrate deeper into the atmosphere, we found a reduction of the peak ozone density in periods of enhanced particles' fluxes. Such a response is widely explained by the activation of $\mathrm{HO}_{x}$ and $\mathrm{NO}_{x}$ ozone destructive cycles. At mid-latitudes, however, the stratospheric part of the $\mathrm{O}_{3}$ profile remains insensitive to these lower energy particles, because they affect only the thermospheric and mesospheric $\mathrm{O}_{3}$. On the other hand, the "hard" protons, emitted during the third solar flare on 20 January, are able to propagate much deeper, affecting even the stratospheric ozone and reducing its density. As a consequence of the thinning of the ozone optical depth, the solar UV penetrates deeper into the atmosphere, activating the Slanger's mechanism for ozone production at lower levels - known also as ozone self-restoration. This could be an explanation for the obtained raise of the mid-latitude peak $\mathrm{O}_{3}$ density in the period of atmospheric restoration after the SPE'2005.

The earlier raise of the polar ozone maximal density - i.e. between 18 and 21 January could be related to the fact that at the moment of SPE'2005 it has been already diminished by the relativistic electrons and "soft" protons, getting ahead of the strongest proton flare. So the further ozone destruction (by particles with mixed energies) triggered the activation of its restoration several days earlier. Consequently, the latitudinal differences in the ozone response - found in ERA Interim data - could be attributed to the different energetic spectrum of solar flares, the depth of the particles' penetration into the atmosphere and the zenith angle of stratosphere illumination by the solar UV radiation. Enhancement of the lower and middle stratospheric temperature during the SPE'2005 has to be attributed to the increased ozone density and the more solar UV radiation absorbed.
\end{abstract}

\section{Introduction}

The middle atmosphere response to the influence of energetic particle (emitted by the solar proton events) is investigated by many authors [1-12], with 
most of them focusing their attention on the ozone depletion at polar latitudes. The possibility for ozone enhancement has been predicted by Jackman et al., [13] using the 2D chemical-transport model of NASA Goddard Space Flight Centre. While the mechanism for ozone depletion is pretty clear (i.e. due to the activation of the ozone destructive cycles by the increased amount of $\mathrm{NO}_{\mathrm{x}}$ and $\mathrm{HO}_{\mathrm{x}}$ families), the mechanism of $\mathrm{O}_{3}$ enhancement was unclear. Jackman et al., [13] attributed it to the downward transportation of the $\mathrm{NO}_{\mathrm{x}}$, which could transform the active chlorine and bromine families into their reservoir species, reducing in such a way the ozone destruction in the lower polar stratosphere.

This explanation is however, non applicable to the raise of the midlatitudes total ozone density, which has been reported by Krivolutsky [2]. The latter related the ozone raise to the enhanced solar electromagnetic radiation (accompanying the corpuscular one) and corresponding acceleration of the photolysis of the molecular oxygen.

Being one of the most absorbing gases in the stratosphere, the ozone plays a key role in the thermo-dynamical regime of the stratosphere-troposphere system. For this reason the determination of factors altering its variability is of great importance. This article investigates altitude-latitude distribution of $\mathrm{O}_{3}$ and temperature anomalies (i.e. their deviation from the climatology) before, during and after the January 2005 SPE at the longitude of Greenwich meridian. We focus our attention on the short term response of the stratospheric $\mathrm{O}_{3}$ and temperature (T) to different spectrum of impacting particles.

\section{Data and methods}

Ozone and $\mathrm{T}$ profiles at the Greenwich meridian have been derived from ERA Interim reanalysis. The intensity of solar proton fluxes - measured on board the geostationary spacecrafts GOES 10 and 11 - has been used in statistical analyses to estimate the efficiency of solar particles' influence on the stratospheric $\mathrm{O}_{3}$ and $\mathrm{T}$ meridional profiles. The effect of the variable solar UV radiation is estimated using data for the solar radio emission at $10.7 \mathrm{~cm}\left(\mathrm{~F}_{10.7}\right)$, taken from http://spidr.ngdc.noaa.gov. Data for cosmic ray intensity (i.e. highly energetic particles with galactic origin) are taken from the Climax neutron monitor.

Before applying any statistics, we calculate the "anomalies" of all atmospheric parameters (i.e. their deviations from the climatological means for January, calculated from the whole data records, i.e. 1979-2009 of ERA Interim reanalysis). To identify the short term response of $\mathrm{O}_{3}$ and $\mathrm{T}$ to different forcing factors we have used the Partial Least Square regression technique (PLS). The PLS regression generalizes and combines features from principal components analysis and multiple regression. It is particularly useful when we search for relations between a set of dependent variables (in our case $\mathrm{O}_{3}$ or $\mathrm{T}$ at all 21 levels from 925 to $1 \mathrm{hPa}$, for given latitude) and a set of independent variables (predictors) during a 
short period of time. PLS regression analysis can be used even when the number of observations is small compared to the number of predictors. PLS searches for a set of components that performs a simultaneous decomposition of matrixes of dependent variables $\mathrm{Y}$ and predictors $\mathrm{X}$. The main constraint is that these components must explain as much as possible of the covariance between $\mathrm{X}$ and $\mathrm{Y}$. When a simultaneous impact of several predictors is estimated, each PLS component is a weighted function of the impact of different predictors. We have performed the PLS analysis for each of the forcing factors separately, but simultaneously at all levels, which ultimately gives us the maximum impact of each examined factor in the observed $\mathrm{T}$ and $\mathrm{O}_{3}$ profiles.

\section{Atmospheric short term response to proton forcing}

January 2005 is characterized by a sequence of 3 intensive solar flares on 15, 17 and 20 January, followed by the largest ground level event ${ }^{1}$ measured by neutron monitors since 1956 [14-16]. The anomalies in temperature and ozone profiles, derived from ERA Interim reanalysis, are presented in Fig. 1. The figure gives a first impression for the Northern hemisphere stratospheric response to precipitating solar energetic particles during January 2005 SPE. It is well seen that since $17^{\text {th }}$ January the lower to middle stratosphere is warmer by up to $12 \div 16^{0} \mathrm{~K}$ while the $\mathrm{O}_{3}$ mixing ratio is higher by $1 \div 3$ ppmv (part per million by volume). These anomalies persist until the end of January, and appear again on 7 February, lasting for another week or so. Complimentary to the results of Fedulina [1], showing a well pronounced depletion in the $\mathrm{O}_{3}$ concentration and $\mathrm{T}$ below $20 \mathrm{~km}$, we found out that the mid-latitude stratospheric response to the January 2005 SPE, manifest itself with an increased ozone mixing ratio and temperature raise at $20 \div 30 \mathrm{~km}$ altitude. Both anomalies appear around $40 \div 60^{\circ} \mathrm{N}$ latitude and expand slowly with time toward the equator.

The reasonable question raised from Fig. 1 is whether these $\mathrm{T}$ and $\mathrm{O}_{3}$ anomalies are related to the solar proton event or appear coincidently? As independent variables, used in the Partial Least Square regression analysis (PLS), have been selected: solar radio emission at $10.7 \mathrm{~cm}\left(\mathrm{~F}_{10.7}\right)$, integral electron flux with energies $\mathrm{E}>2 \mathrm{MeV}$, integral soft proton flux with energies $\mathrm{E}>1 \mathrm{MeV}$ and the flux of hard protons with $\mathrm{E}>60 \mathrm{MeV}$, as well as the galactic cosmic rays (CRs). To analyse the time evolution of the forcing factors and corresponding $\mathrm{T}$ and $\mathrm{O}_{3}$ response, we have examined three periods (characterised by a different spectrum of precipitating energetic particles) i.e. 9-19 January, 17-27 January and 28 Jan-07 February.

Examination of the solar protons with energies $\mathrm{E}>1 \mathrm{Mev}$ and $\mathrm{E}>60 \mathrm{MeV}$ (shown in Fig. 2) reveals that during the second solar flare (on 17 January) the

\footnotetext{
${ }^{1} \mathrm{~A}$ sharp increase in the ground-level count of cosmic rays by neutron monitors (at least by $5 \%$ above background) associated with solar protons of energies $>500 \mathrm{MeV}$.
} 
"soft" protons' intensity is much higher than that of the "hard" protons. The most powerful flare is observed on 20 January 2005 , characterised by a sharp increase of the "hard" protons' spectra. On the next day -21 January, there is another peak in the "soft" protons' intensity, but it is more than twice weaker than the first one.

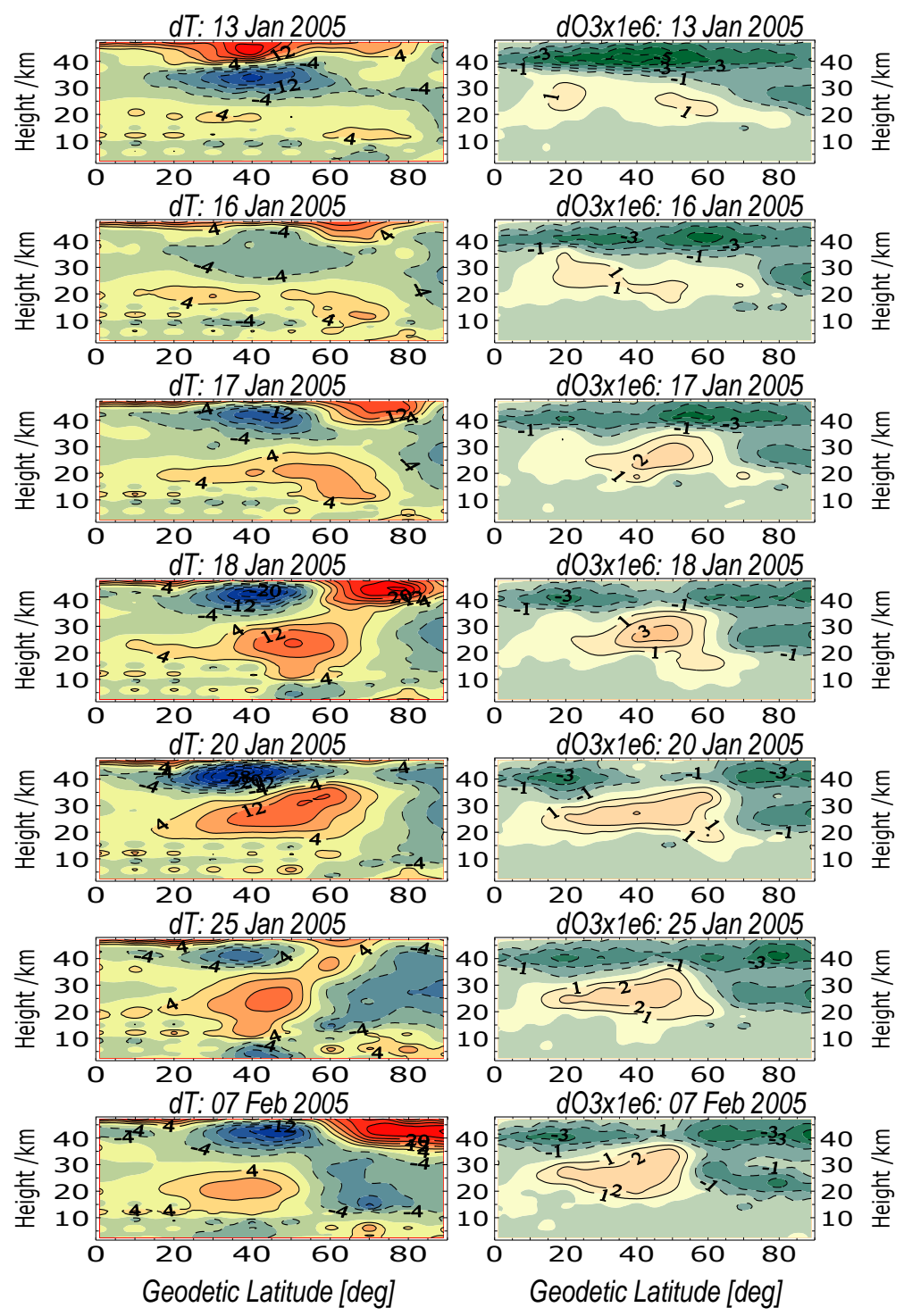

Fig. 1. Meridional cross-section of $\mathrm{T}$ and $\mathrm{O}_{3}$ anomalies before, during and after January 2005 Solar Proton Events. The $\mathrm{O}_{3}$ contour labels [ppmv] have to be multiplied by $10^{-6}$.

Dash contours indicate negative anomalies. 
Protons from GOES $10 \& 11$ and CRs from Clima

for the period 17Jan - 07 Feb'05

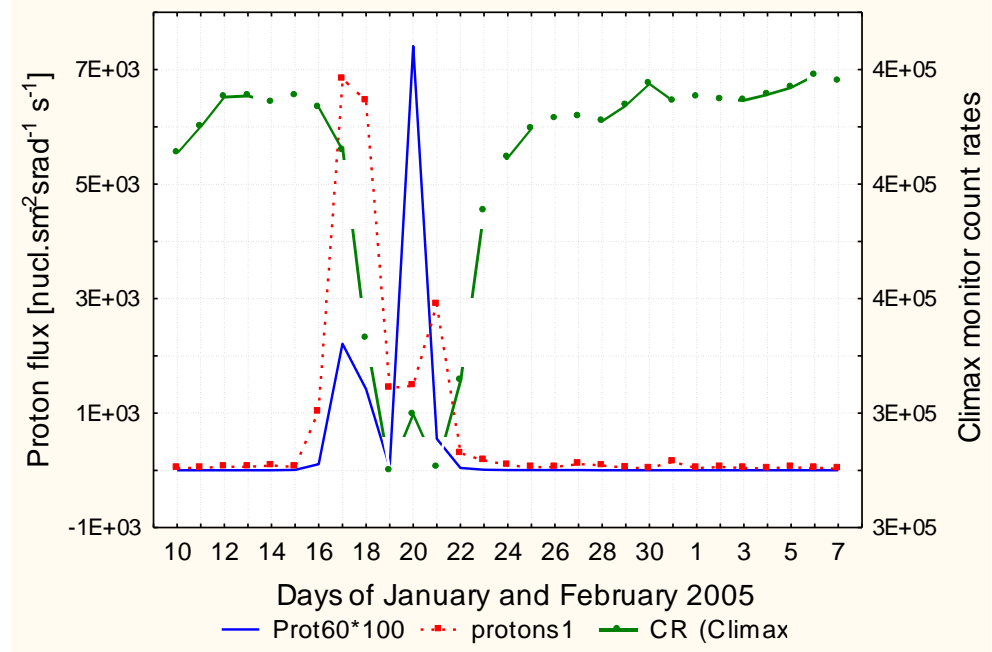

Fig. 2. Time series of protons with energy $\mathrm{E}>1 \mathrm{MeV}$ (protons 1 ) and with $\mathrm{E}>60 \mathrm{MeV}$ (prot60) compared with the Forbush decrease of galactic cosmic rays

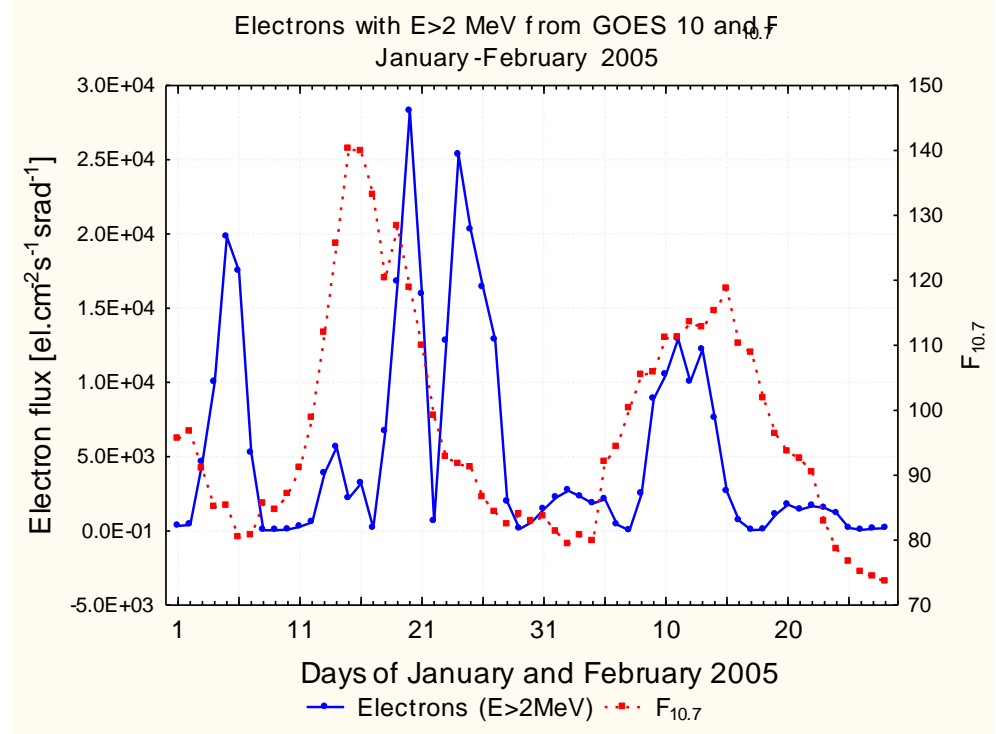

Fig. 3. Time series of the integral electron flux with energy $E>2 \mathrm{MeV}$, measured on board the GOES 10 satellite (continuous line with dots), and solar radio emission at $10.7 \mathrm{~cm}$ $\left(F_{10.7}\right)$ - a proxy of solar UV radiation (dashed line with squares) 
Figure 3 illustrates, in addition, the temporal variability of the relativistic electrons, measured on board the GOES 11 satellite. It is worth noting that their temporal variability is determined by the the high speed solar wind streams (emanated from the solar coronal holes), which enhance the population of energetic electrons (with $\mathrm{E}>4 \mathrm{KeV}$ ) in the magnetosphere and modulate their precipitation into the lower thermosphere and mesosphere [17]. The examination of the time series of relativistic electrons with energies $>2 \mathrm{MeV}$, measured on GOES 10 satellite, for the period 2000-2009, shows that their intensity is an order of magnitude higher in the period 2003-2006. This is obviously related to the fact that solar wind streams become more intensive and recurrent, when the Sun approaches the minimum of its 11 year cycle.

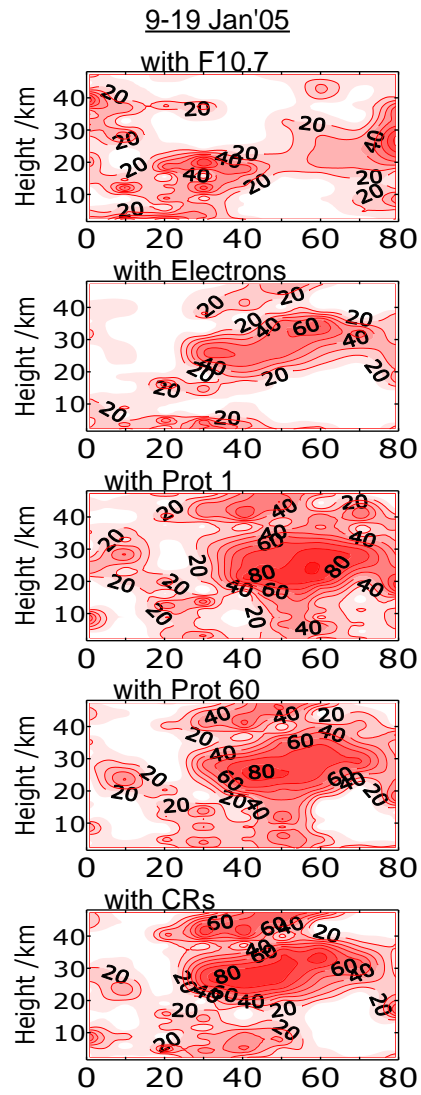

Northern Latitude [deg]
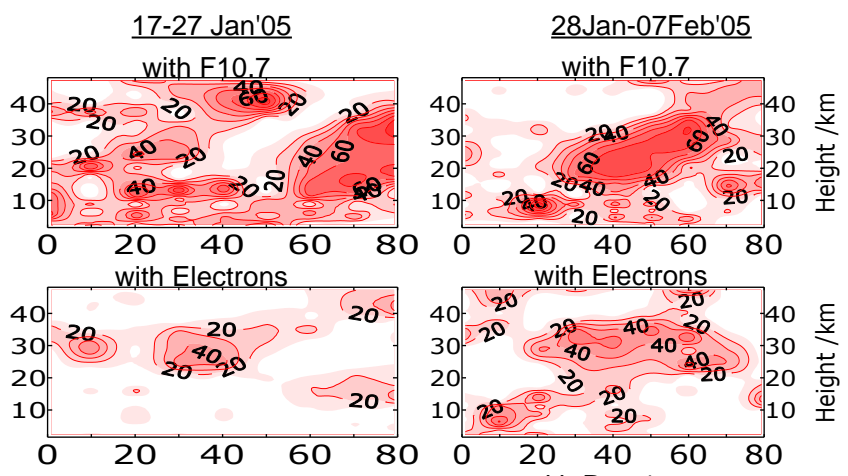

with Prot 1

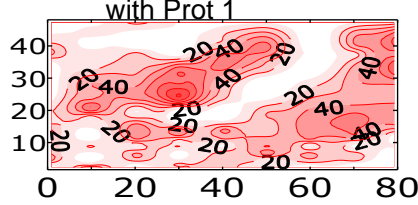

$$
\text { with Prot } 60
$$

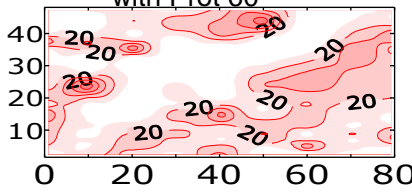

with CRs

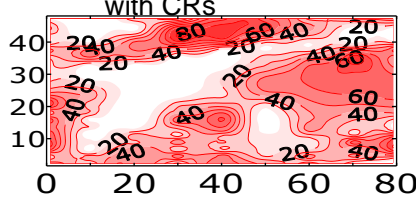

Northern Latitude [deg]
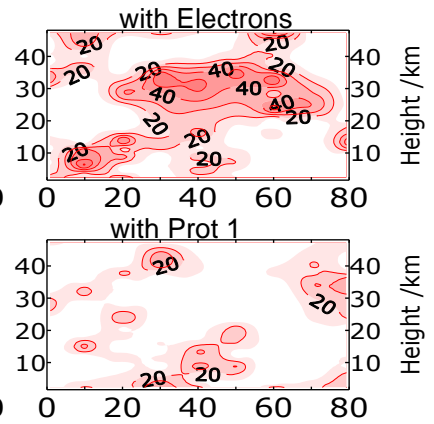

with Prot 60

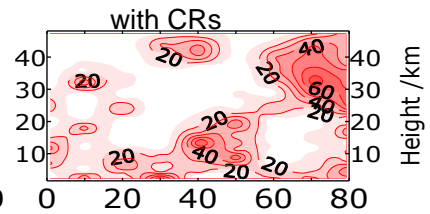

Northern Latitude [deg]

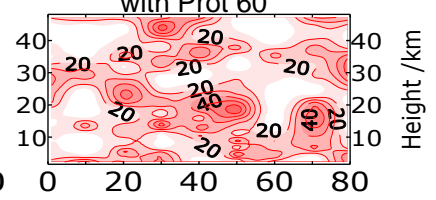

Fig. 4 (a). Percentage impact of the solar UV radiation $\left(1^{-s r}\right.$ row), electrons with $E>2 \mathrm{MeV}$

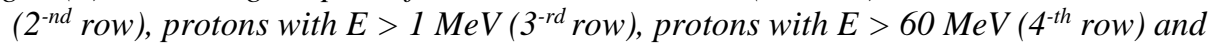
cosmic ray flux (from Climax neutron monitor) in temperature variability for the period 10 January - 7 February 2005 
Within the investigated period, the first raise of the relativistic electrons' intensity has appeared between $4^{\text {th }}$ and $7^{\text {th }}$ January - i.e. 3 day before the first and 10 days before the second solar flare. Furthermore, there are two more picks - on $20^{\text {th }}$ and $23^{\text {th }}$ January - obviously related to the SPE'2005, and another raise between $10^{\text {th }}$ and $14^{\text {th }}$ February. In addition, the 27-day periodicity of the solar UV radiation is also showed in Fig. 3.

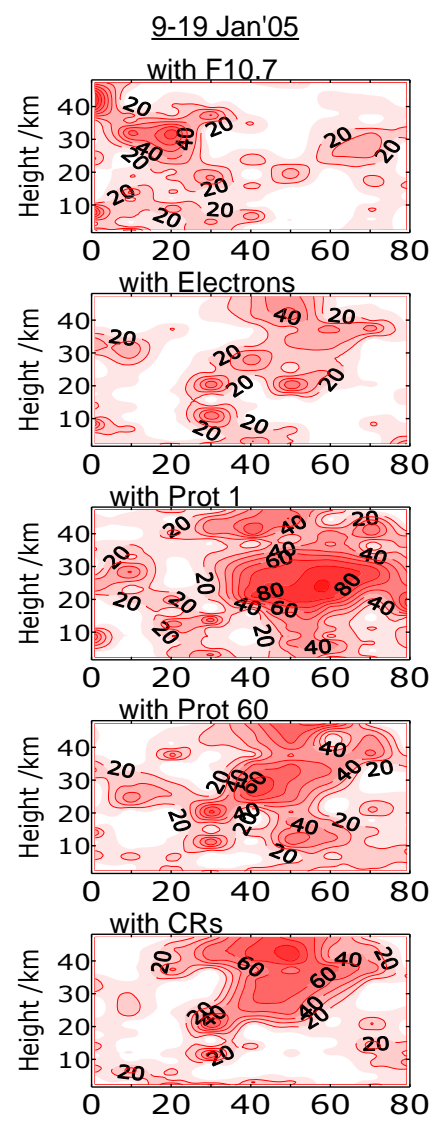

Northern Latitude [deg]
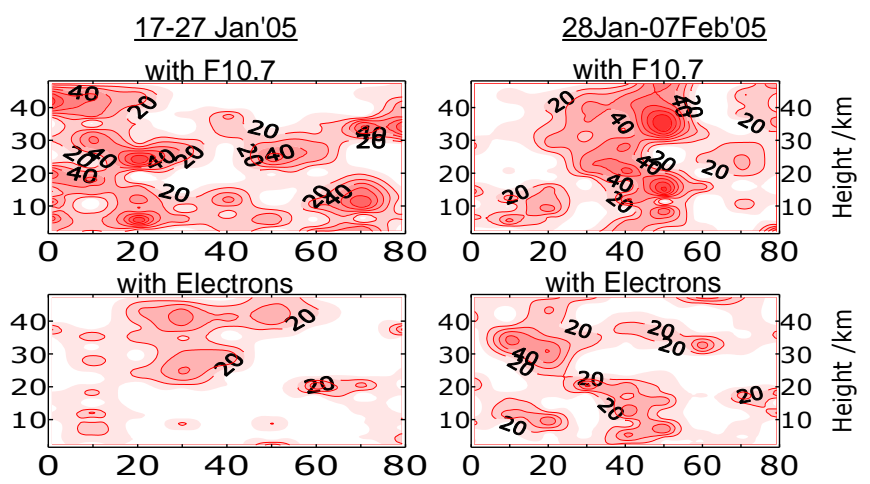

with Prot

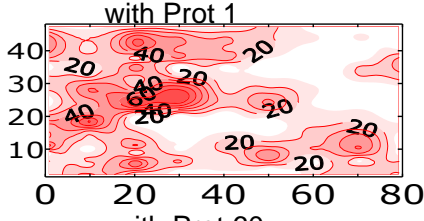

with Prot 60

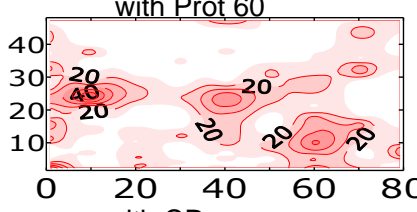
with CRs

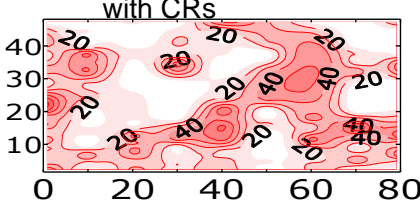

Northern Latitude [deg]
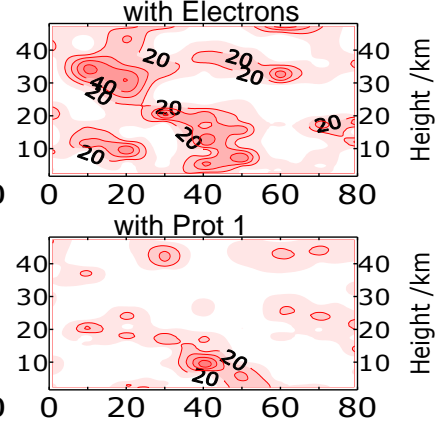

with Prot 60

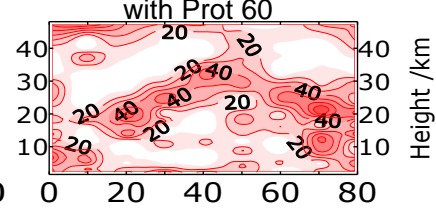

with CRs

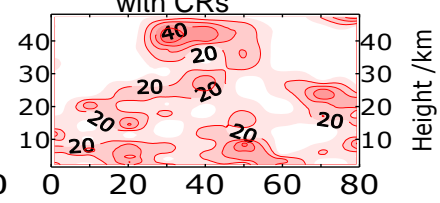

Northern Latitude [deg]

Fig. 4(b). Percentage impact of the solar UV radiation and energetic particles in ozone variability during the period 10 January - 7 February 2005

Figure 4 presents the calculated coefficient of determination $\mathrm{R}^{2}$ multiplied by 100 , which gives the percentage impact of each factor in $\mathrm{T}$ and $\mathrm{O}_{3}$ variability. The analysis of Fig. 4(a) shows that middle-stratospheric warming during the first analysed period (refer to Fig. 1) could be attributed mainly to three of the examined factors: (i) increased density of "soft" protons, having a maximum at $17-18^{\text {th }}$ 
January, which describe up to $80 \%$ of T variability, (ii) the enhancement of "hard" protons and (iii) the Forbush decrease of GCR. The impact of the last two factors is about $70 \div 80 \%$ of the T variability. The particles' impact, however, seems to be short lasting and during the second and third time intervals is strongly weakened and dispersed (see the middle and right columns of Fig. 4(a)). In the second half of January two other factors become particularly important - i.e. the solar UV radiation and the relativistic electrons (with $\mathrm{E}>2 \mathrm{MeV}$ ). Each of them explains up to $60 \%$ of the $\mathrm{T}$ variability (Fig.4(a), middle and right columns).

The ozone's response to the analysed forcing agents is shown in Fig. 4(b). It is easily noticeable that before the solar proton event, the mid- and high latitude $\mathrm{O}_{3}$ variability is closely related to the particles intensity - soft and hard solar protons and cosmic rays (Fig. 4(b), left column). During the main phase of the SPE'2005, as well as during the atmospheric recovery phase, the particles effect on the $\mathrm{O}_{3}$ is substantially diluted. As should be expected, the "soft" protons impact is minimised during the recovery phase, due to the severe decrease of their flux intensity (refer to Fig. 2). The "hard" protons' effect, however, does not disappear for the same reason, which is a hint for existing mechanism ensuring delayed $\mathrm{O}_{3}$ response to the high speed protons. The impact of relativistic electrons remains noticeable during the recovery phase, due to subsequent spike in their intensity (refer to Fig. 3). The gradual increase of CR intensity, after the Forbush decrease (see Fig. 2), is also well traceable in $\mathrm{O}_{3}$ variability (the right column in Fig. 4(b). The most important at this period seems the solar UV radiation - especially at middle latitudes - possibly due to the raise of its intensity.

\section{Analysis of ozone profiles' response to particles' forcing}

The current section is aimed to examine the variability of the ozone's vertical profiles and if possible to attribute some specificity in its behaviour to the energetic particles' fluxes. Figures 5 and 6 provide a direct view on the vertical profiles of $\mathrm{O}_{3}$ anomalies - i.e. its deviations from the $\mathrm{O}_{3}$ climatology for January, calculated over the entire data record (1979-2009) - at all examined 21 levels. Due to the spectral difference of energetic particles' temporal variations, we have selected three periods in their temporal variability: (i) non-SPE conditions 3-8 January, characterised by raised integral flux of relativistic electrons between $4^{\text {th }}$ and $7^{\text {th }}$ January; (ii) the main phase of SPE'2005 (18-21 January) - characterised by a sharp increase of the "hard" solar protons (on $20^{\text {th }}$ January) and a spike in the flux of relativistic electrons (within 19-21 January); (iii) the recovery phase after the SPE'2005 (23-27 January). The variability of $\mathrm{O}_{3}$ profiles at $60^{\circ} \mathrm{N}$ and $40^{\circ} \mathrm{N}$ latitude, at Greenwich meridian, have been examined and compared.

The top panels of Fig. 5 reveal that the enhanced flux of relativistic electrons is accompanied by an increased variability of the high latitude ozone profile beneath $20 \mathrm{~km}$, while their effect at mid-latitudes is substantially 
suppressed. The ozone's response to the mixed forcing (i.e. "soft" and "hard" protons, and relativistic electrons) during the SPE'2005 is more complicated especially at high latitudes. The bottom panels of Fig. 5 shows a sudden enhancement of the peak $\mathrm{O}_{3}$ density at $60{ }^{\circ} \mathrm{N}$ latitude - immediately after the raise of the "soft" protons' flux (on 17-18 January), as well as during the peak of relativistic electrons (on 20 January), followed by the second spike in "soft" protons (on 21 January). The mid-latitude $\mathrm{O}_{3}$ is practically insensible to these lower energetic particles - with an exception of $19^{\text {th }}$ January, when the ozone density at $18 \mathrm{~km}$ was enhanced by $\sim 40 \%$ (Fig. 5, bottom, right column).
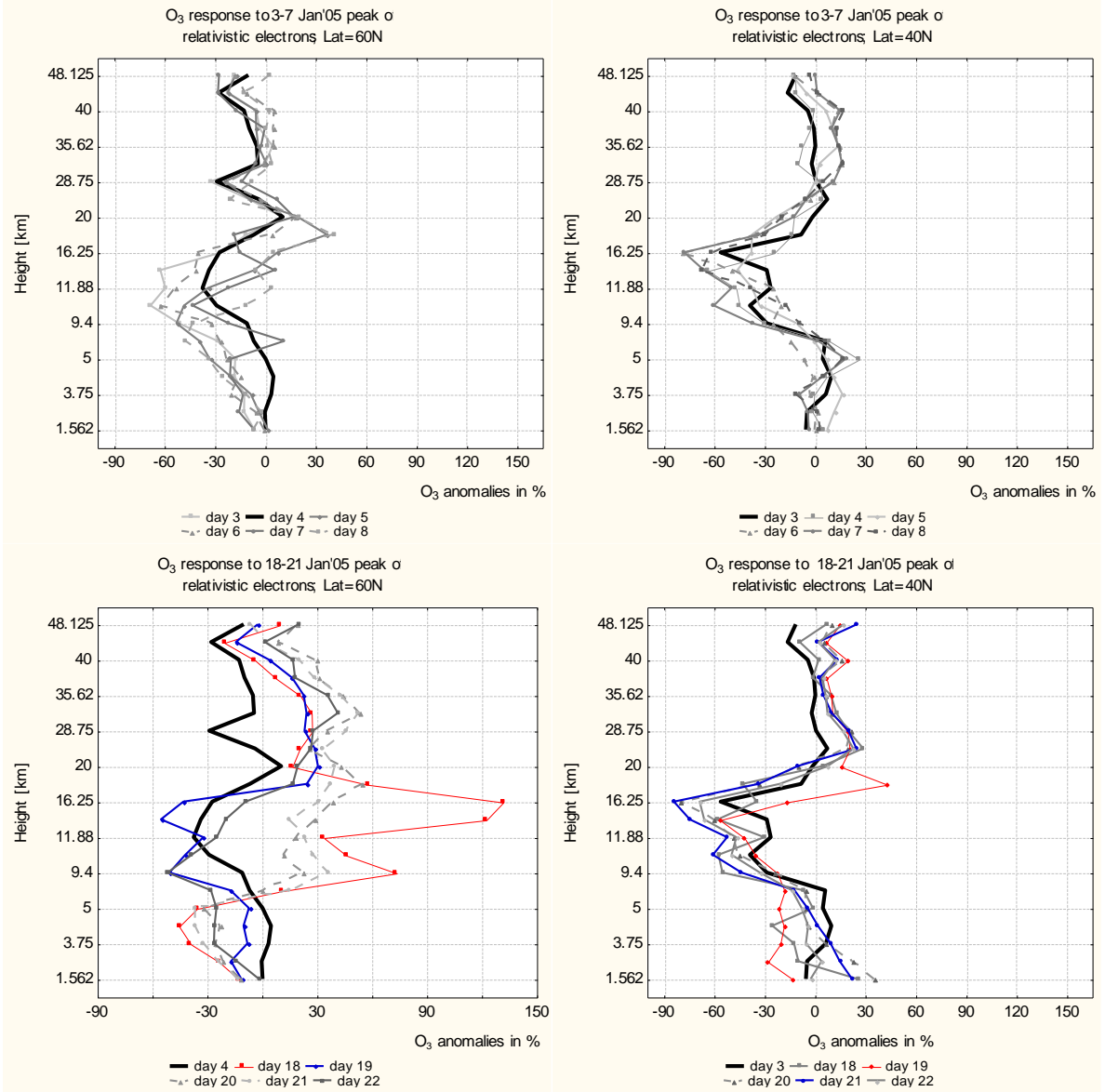

Fig. 5. Ozone profiles' variations at $60^{\circ} \mathrm{N}$ (left colun) and $40^{\circ} \mathrm{N}$ (right) column, found prior to and during the solar proton event in January 2005. Ozone profiles from 3 and 4 January (thick black lines) are choosen as undisturbed ones. 
The recovery phase after the SPE'2005 is characterised by a stable depletion of the polar ozone - up to $70 \%$ compared to the January climatology (left panel of Fig. 6) - probably related to the downward transportation of $\mathrm{NO}_{\mathrm{x}}$ family from the mesospheric levels, where they are produced. Much more surprising, during the recovery phase, is the mid-latitude $\mathrm{O}_{3}$ behaviour. Thus, with an exception of $23^{\text {th }}$ January, all other days (i.e. $24^{\text {th }}-27^{\text {th }}$ January) are characterised by a dramatically increased $\mathrm{O}_{3}$ density - more than $150 \%$ (the right panel of Fig. 6). This ozone enhancement is hardly understandable, despite the coincidence with the $3^{\text {-rd }}$ sharp peak in the relativistic electrons flux. The lower energy of these particles does not allow them to penetrate deeper into the atmosphere, due to the geomagnetic shielding, and could not directly influence the exceptional $\mathrm{O}_{3}$ behaviour. Fig. 3 shows, in addition, that the raise of the peak ozone density should not be attributed to the solar UV radiation, because it was in the minimum of its 27-day periodicity.
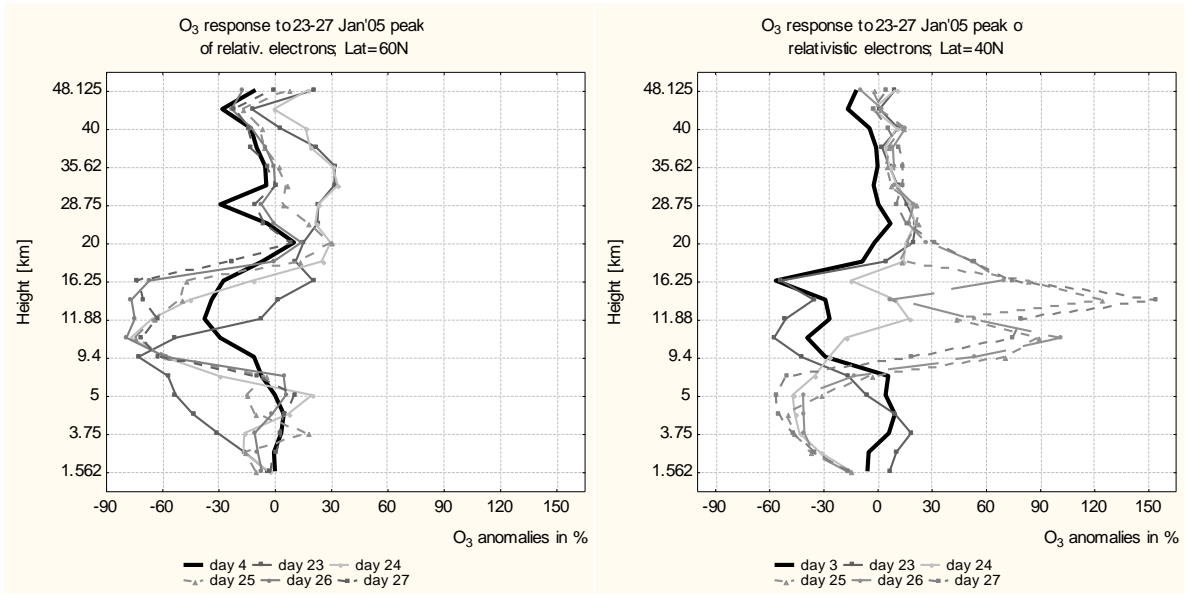

Fig. 6. Ozone profiles'variations at $60^{\circ} \mathrm{N}$ (left colun) and $40^{\circ} \mathrm{N}$ (right) column, found during the atmospheric recovery after the solar proton event in January 2005.

An attempt for explanations of this latitudinal variability of $\mathrm{O}_{3}$ response to the particles' forsing, during the solar proton event in January 2005, will be given in the next section.

\section{Mechanism of $\mathrm{O}_{3}$ enhancement during and after January'2005 SPE}

It is broadly accepted that the main effect of precipitating energetic particles in the Earth's atmosphere is the $\mathrm{O}_{3}$ destruction, due to the activated $\mathrm{HO}_{\mathrm{x}}$ (i.e. $\left.\mathrm{H}, \mathrm{OH}, \mathrm{HO}_{2}\right)$ and $\mathrm{NO}_{\mathrm{x}}\left(\mathrm{NO}, \mathrm{NO}_{2}\right)$ ozone destructive cycles $[18,19]$. The satellite measurements and modeling results show that enhanced $\mathrm{HO}_{\mathrm{x}}$ and $\mathrm{NO}_{\mathrm{x}}$ densities can significantly impact the concentration of the mesospheric ozone. 
Their influence on the stratospheric $\mathrm{O}_{3}$, however, goes mainly through a modulation of the ozone's optical depth (i.e. the ozone column aloft a given stratospheric level).

The thinning or thickening of the $\mathrm{O}_{3}$ optical depth increases or decreases the amount and spectral characteristics of the penetrating solar UV radiation. In normal conditions, the solar UV radiation - capable of reaching the middle stratosphere - could not dissociate molecular oxygen $-\mathrm{O}_{2}$ [20], and consequently it could not produce ozone at these levels. However, [21] noticed that the large UV continuum, known as Hartley band $(200 \div 350 \mathrm{~nm})$, is able to dissociate ozone creating vibrationally excited molecular oxygen $\mathrm{O}_{2}{ }^{*}$. The latter is easily issociated by the freely penetrating at these levels longer UV radiation, creating atomic oxygen. The latter immediately reacts with the oxygen molecules, creating ozone, i.e.

$$
\begin{aligned}
& \mathrm{O}_{3}+\mathrm{h} v(248 \mathrm{~nm}) \rightarrow \mathrm{O}_{2}{ }^{*}+\mathrm{O} \\
& \mathrm{O}_{2}{ }^{*}+\mathrm{h} v(>300 \mathrm{~nm}) \rightarrow 2 \mathrm{O} \\
& 3 \mathrm{O}+\mathrm{O}_{2} \rightarrow 3 \mathrm{O}_{3}
\end{aligned}
$$

Net: $1 \mathrm{O}_{3} \rightarrow 3 \mathrm{O}_{3}$

In resume, dissociation of a one ozone molecule by solar UV radiation leads to the formation of three new ozone molecules. This effect is known as ozone "self-restoration" and has been explained for the first time by Slanger [20].

This mechanism could be activated, when occasionally the thermosphere-mesospheric $\mathrm{O}_{3}$ is reduced, which allows more UV radiation to reach the stratosphere. The efficiency of the ozone self-restoration has been estimated by Kilifarska et al. [21], which created a chemical model of this effect. Using their formula (6) we have estimated the changes in the $\mathrm{O}_{3}$ profile resulting from a uniform reduction of its optical depth $\left(\tau_{3}\right)$ by $30 \%$ above $35 \mathrm{~km}$. Calculations have been made at two latitudes $-40^{\circ} \mathrm{N}$ and $60^{\circ} \mathrm{N}-$ using the ERA Interim data for 13 January (up to the stratopause) as non-disturbed $\mathrm{O}_{3}$ and $\mathrm{T}$ profiles. The mesospheric $\mathrm{T}$ and $\mathrm{O}_{3}$ concentration, as well as the whole profile of the molecular $\mathrm{O}_{2}$ have been taken from the US standard atmosphere (1976). The concentrations of the $\mathrm{OH}$ radical for examined days have been taken from the MLS instrument on board the AURA satellite.

Results presented in Fig. 7 show that the reduction of the ozone optical depth aloft $35 \mathrm{~km}$ is really followed by an $\mathrm{O}_{3}$ increase at lower levels. This process, however, depends on the solar zenith angle $(\chi)$ and the latitude. Thus at mid-latitudes the enhancement of the $\mathrm{O}_{3}$ concentration is maximal near the peak of the ozone layer during sunlight hours. At sunset, however, (calculations are made for $\chi=89^{\circ}$ and $105^{\circ}$ ) a distortion of the $\mathrm{O}_{3}$ profile is found above $35 \mathrm{~km}$, while the enhancement of the peak $\mathrm{O}_{3}$ density near $25 \mathrm{~km}$ is strongly reduced (see the left side of Fig. 7). 


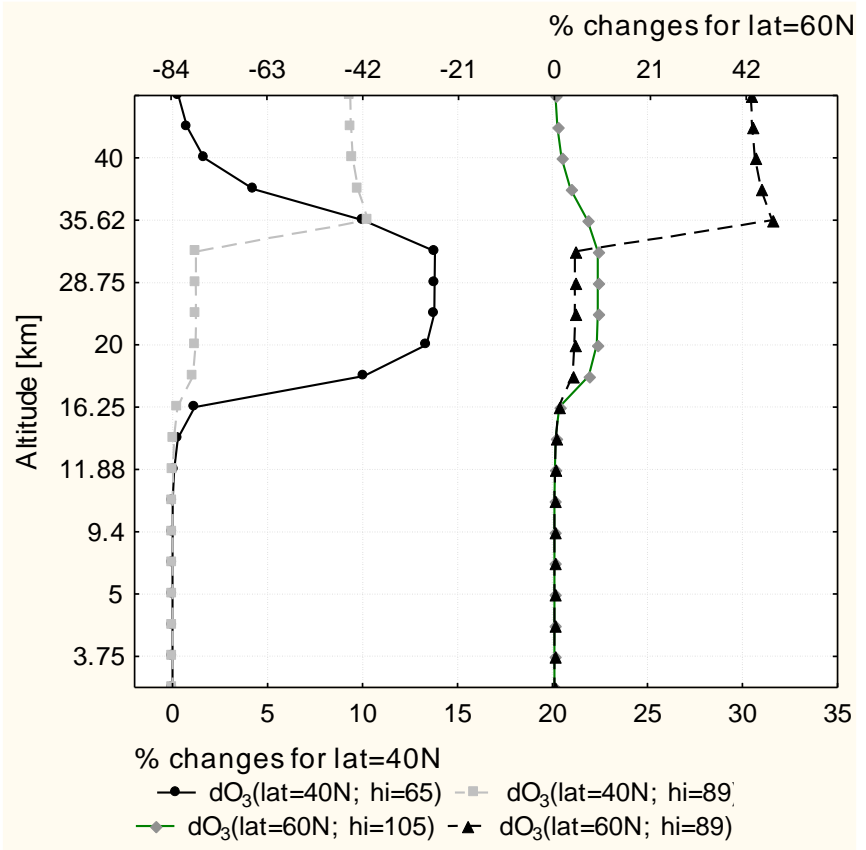

Fig. 7. Ozone response at the middle (left) and the polar latitudes (right) to a $30 \%$ reduction of its optical depth above $35 \mathrm{~km}$, calculated by the [14] model. The continuous line with dots gives the $\mathrm{O}_{3}$ profile at $40^{\circ} \mathrm{N}$ calculated with a solar zenith angle $\chi=65^{\circ}$, while dashed line with squares corresponds to $\chi=89^{\circ}$ (left side of the figure); continuous line with diamonds corresponds to $\mathrm{O}_{3}$ profile at $60^{\circ} \mathrm{N}$ calculated for $\chi=105^{\circ}$, and long dashes with triangles - corresponds to $\chi=89^{\circ}$ (right part of the figure).

In January the mid-day value of the solar zenith angle at $60^{\circ} \mathrm{N}$ latitude is $89^{\circ}$ and the calculated changes in the $\mathrm{O}_{3}$ profile are found out above $35 \mathrm{~km}$, reaching the values of $42 \div 44 \%$ increase of ozone density. Unlike the mid-latitudes, the model predicts a slight enhancement of the middle stratospheric ozone density for higher zenit angles, i.e. $\chi>90^{\circ}$ (presented are calculations for $\chi=105^{\circ}$; see the right side of Fig. 7). It is worth noting that the ozone self-restoration effect depends strongly on the lowest boundary of the mesospheric $\mathrm{O}_{3}$ depletion. The effect is stronger, when the negative $\mathrm{O}_{3}$ anomalies reach the upper stratosphere [21]. The results shown in Fig. 7 are a rough estimation of the self-restoration effect, because only the $\mathrm{O}_{3}$ absorption at $250 \mathrm{~nm}$ is taken into account. More realistic results can be derived when the entire Harley and Schuman-Runge bands are included in the calculations.

The model's estimations shown in Fig. 7 could help us to understand the irregular response of $\mathrm{O}_{3}$ profile at polar and mid-latitudes, due to the energetic particles' impact. For example, the puzzling enhancement of the polar peak $\mathrm{O}_{3}$ 
density during the SPE'2005 (bottom, left panel in Fig. 5) could be attributed to the reduced $\mathrm{O}_{3}$ optical depth, preconditioned by the increased flux of relativistic electrons since the beginning of January 2005 (refer to Fig. 3). The raise of "soft" protons in $17-18^{\text {th }}$ January makes the polar $\mathrm{O}_{3}$ column even thinner. At these circumstances, the higher zenith angle of the solar UV radiation illuminating the middle stratosphere, activates the self-restoration mechanism near the peak of the $\mathrm{O}_{3}$ layer (refer to the right grey $\mathrm{O}_{3}$ profile in Fig. 7).

At mid-latitudes, the ozone self-restoration is activated after the SPE'2005. This behaviour could be attributed to the less sensitivity of the mid-latitude stratospheric $\mathrm{O}_{3}$ to the lower energetic protons and electrons, penetrating the upper atmosphere before and during the SPE'2005. However, the "hard" protons striking the atmosphere on $20^{\text {th }}$ January, reduces the $\mathrm{O}_{3}$ density deeper into the stratosphere (see the right, bottom panel of Fig. 5). In accordance with the model's simulations [21], the $\mathrm{O}_{3}$ reduction at stratospheric levels serves as a trigger for activation of the self-restoration mechanism.

\section{Conclusions}

Thorough analysis of the atmospheric response to energetic particles' forcing (during Solar Proton Event SPE'2005 on 20 January 2005), shows that the stratospheric $\mathrm{O}_{3}$ is very sensitive to the energy spectrum of penetrating energetic particles, as well as on the latitude. The evaluation and modeling of the cosmic ray interaction with the substance of the stratosphere is done by means of full Monte Carlo simulations and appropriate hadron and atmospheric models [22-25].

Evidence for an enhanced maximal $\mathrm{O}_{3}$ density at polar latitudes and a decreased one at mid-latitudes is shown during the strongest, and with "hard" particles' spectrum, solar flare. During the recovery phase has been found the opposite response - i.e. raised mid-latitude and reduced polar ozone density.

These irregularities have been attributed do the modulation of ozone's optical depth, due to the activation of the $\mathrm{HO}_{\mathrm{x}}$ and $\mathrm{NO}_{\mathrm{x}}$ ozone destructive cycles at thermospheric and mesospheric levels. Thus thinning of the $\mathrm{O}_{3}$ optical depth activates the Slanger's mechanism for ozone formation at lower atmospheric levels - an effect known also as $\mathrm{O}_{3}$ self-restoration. We demonstrate that efficiency of ozone's self-restoration depends on the zenith angle of stratospheric illumination by the solar UV radiation - especially important at high latitudes.

The observed warming of mid-latitude stratosphere, during the SPE'2005, has been attributed to the ozone enhancement and the more solar UV radiation absorbed. The influence of high energy particles on the stratosphere continues further down to the troposphere and results in various meteorological and climatic effects [26]. 


\section{References}

1. Fedulina, I. N. Changes of ozone contents at middle latitudes during Forbush decreases of cosmic rays, Studia Geoph. Geod., 1998, 42, 521-32.

2. Krivolutsky, A. A. Global structure of ozone response to solar and galactic cosmic ray influence (Ground based and satellite data analysis), Adv. Space Res., 1999, 24, 5, 641-48.

3. Krivolutsky, A. A., Klyuchnikova, A. V., Zakharov, G. R., Vyushkova, T. Yu., and Kuminov, A. A. Dynamical response of the middle atmosphere to solar proton event of July 2000: Three-dimensional model simulations, Adv. Space Res., 2006, $37,1602-13$.

4. Seppälä, A., Verronen, P., Sofieva, V., Tamminen J., and Kyrola, E. Destruction of the tertiary ozone maximum during a solar proton event, Geophys. Res. Lett., 2006, 33, L07804, doi:10.1029/2005GL025571.

5. Tassev, Y., Velinov, P. I. Y., and Tomova, D. Increase of stratospheric ozone in Pfotzer maximum due to solar energetic particles during Ground Level Enhancement of cosmic rays on 20 January 2005, C. R. Acad. Bulg. Sci., 2006, 59, 11, 1153-59.

6. Tassev, Y., Velinov P. I. Y., Mateev L., and Tomova D. Comparison Between Effects of Solar Proton Events and Geomagnetic Storms on the Ozone Profiles. Adv. Space Res., 2003, 31, 9, 2163-68.

7. Tassev, Y.K., Yanev T., Velinov P. I. Y., Mateev L. Variations in the ozone profiles during the solar proton events from October 19-31, 1989. Adv. Space Res., 1999, 24, 5, 649-55.

8. Tassev, Y.K., Yanev T., Velinov P. I. Y., and Mateev L. Ozone variations in the middle atmosphere due to solar proton event from 19 October 1989.. C. R. Acad. Bulg. Sci., 1997, 50, 3, 35-38.

9. Tassev, Y., Spassov C., and Velinov P. I. Y. On the relationships between vertical ozone distribution and middle atmosphere dynamics during stratospheric warming at solar minimum, Adv. Space Res., 1993, 13, 1, 321-24.

10. Velinov, P. I. Y., Nestorov G., Spassov C., Dachev T., and Tassev Y. Ionospheric and stratospheric effects of proton flare during unusual solar activity on 22 November 1977. Adv. Space Res., 1984, 4, 4, 163-66.

11. Tassev, Y., Velinov P. I. Y., Eroshenko E., Mishev A., Mateev L., Tomova D. Numerical modeling of ozone density in the atmosphere after ground level enhancement of cosmic rays on 20 January 2005. C. R. Acad. Bulg. Sci., (Suppl.) Fund. Space Res., 2010, 63, 137-41.

12. Verronen, P. T., Rodger, C. J., Clilverd, M. A., Pickett, H. M., and Turunen, E. Latitudinal extent of the January 2005 solar proton event in the Northern Hemisphere from satellite observations of hydroxyl. Ann. Geophys., 2007, 25, 2203-15.

13. Jackman, C. H., Fleming, E. L., Vitt, F. M. Influence of extremely large solar proton events in a changing stratosphere, J. Geophys. Res., 2000, 105, D5, 11659-70.

14. Bieber, J., Clem, J., Evenson, P., Pyle R., Duldig M., Humble J., Ruffolo D., Rujiwarodom M., and Sáiz A. Largest GLE in half a century: Neutron monitor observations of the January 20, 2005 event, In: Acharya, B.S., Gupta, S, 
Jagadeesan, P. (Eds.), Proceedings of the 29th International Cosmic Ray Conference, Tata Institute of Fundamental Research, Mumbai, India, 2005, 1, 237-40.

15. Mishev, A., Velinov P. I. Y., Mateev L., and Tassev Y. Ionization effect of solar protons in the Earth atmosphere - Case study of the 20 January 2005 SEP event. Adv. Space Res. 2011, 48, 7, 1232-37.

16. Mishev, A., Velinov P. I. Y., Mateev L., and Tassev Y. Ionization effect of nuclei with solar and galactic origin in the Earth atmosphere during GLE 69 on 20 January 2005. J. Atmos. Solar-Terr. Phys., 2012, 89, 1-7.

17. Thorne, R. M. The importance of energetic particle precipitation on the chemical composition of the middle atmosphere, Pure Appl. Geophys., 1980, 118, 128-51.

18. Rusch, D. W., Gerard J. C., Solomon S., Crutzen P. J., and Reid G. C. The effect of particle precipitation events on the neutral and ion chemistry of the middle atmosphere - I. Odd nitrogen, Planet, Space Sci., 1981, 29, 7, 767-74.

19. Banks, P. M., Kockarts G. Aeronomy - part B, Acad. Press, New York and London, 1973.

20. Slanger, T. G., Jusinski L. E., Black G., and Gadd G. E. A new laboratory source of ozone and its potential atmospheric implications, Science, 1988, 241, 945-50.

21. Kilifarska, N. A., Bakhmutov V. G., and Melnyk G. V. Energetic particles influence on the Southern Hemisphere ozone variability, C. R. Acad. Bulg. Sci., 2013, 66, 11, $1613-22$.

22. Mishev, A. and Velinov P. I. Y. The effect of model assumptions on computations of cosmic ray induced ionization in the atmosphere. J. Atmos. Solar-Terr. Phys., 2010, 72, 476-81.

23. Mishev, A. and Velinov P. I. Y. Normalized ionization yield function for various nuclei obtained with full Monte Carlo simulations. Adv. Space Res., 2011, 48, 19-24.

24. Mishev, A. and Velinov P. I. Y. Influence of hadron and atmospheric models on computation of cosmic ray ionization in the atmosphere - Extension to heavy nuclei. J. Atmos. Solar-Terr. Phys., 2014, 120, 12, 111-20.

25. Mishev, A., Velinov, P. I. Y. Ionization effect in the middle stratosphere due to cosmic rays during strong GLE events. C. R. Acad. Bulg. Sci., 2018, 71, 4, 523-28.

26. Eroshenko, E., Velinov P. I. Y., Belov A., Yanke V., Pletnikov E., Tassev Y., Mishev A., and Mateev L. Relationships between neutron fluxes and rain flows. Adv. Space Res., 2010, 46, 637-41. 


\section{ШИРОЧИННА ЗАВИСИМОСТ НА ВАРИАЦИИТЕ \\ В СТРАТОСФЕРНИЯ ОЗОН И ТЕМПЕРАТУРА ПО ВРЕМЕ НА СЛЬНЧЕВОТО ПРОТОННО СЬБИТИЕ ОТ 20 ЯНУАРИ 2005}

\section{Н. Килифарска}

\section{Резюме}

Статията представя анализ на измененията, наблюдавани във вертикалните профили на озона и температурата на Гринуичкия меридиан, по време на протонното събитие от януари 2005 г. Изследвана е зависимостта от енергетичния спектър на частиците, измерени на геостационарния спътник GOES 11. Показано е, че озонният профил реагира по различен начин на средни и на полярни ширини. Представеното обяснение на тези особенности е базирано на измененията в оптичната пльтност на озона, вследствие на увеличената продукция на озоно-разрушаващите $\mathrm{HO}_{\mathrm{x}}$ и $\mathrm{NO}_{\mathrm{x}}$ семейства. Така намаляването на оптичната пльтност на озона улеснява проникването на слънчевия ултравиолет и активира производството на озон в стратосферата по механизма на Слангер (известен още като самовъзстановяване на озона). Преставени са моделни разчети на произведения по този механизъм озон. Отбелязано е, че чувствителността на стратосферния озон към измененията в оптичната му пльтност зависи, както от енергетичния спектьр на частиците, така и от дълбочината на проникването им в атмосферата (контролирана от геомагнитното поле). Процесът на самовъзстановяването на озона зависи още от зенитния ьгъл на огряване на стратосферата от слънчевия ултравиолет. Ръстът на температура в средната стратосфера по време на протонното събитие е обяснен с увеличената озонна пльтност и по-голямото количество адсорбирана ултравиолетова радиация. 